\title{
THE EFFECT OF TEACHING TECHNIQUES AND TYPES OF PERSONALITY ON ENGLISH LISTENING SKILL
}

\author{
Ni Made Ratminingsih \\ Undiksha Singaraja, Jln, Udayana No.11 Singaraja \\ e-mail: made.retminingsih@pasca.undiksha.ac.id
}

\begin{abstract}
This research aims to know the effects of learning technique and personality The to listening skills in english . this research is an eksperimental research with factorial program $2 \times 2$ which is conducted in primary school laboratoris of UNDIKSHA Singaraja. Eighty eight students are involved in this research, which were chosen randomly by multi stage random sampling technique. This research shows that (1) no significant difference in listening english skills between students using games for learning and students using song for learning. 2) listening skills on english for students who have extroversion personality are better than controversy. 3) there are interaction effects between learning technique and personality type to listening skills in english. 4) listening english skill for extroversion students who are learning by playing is lower than who learning by song, and 5) listening skills in english students who are controversy by playing learning is higher than students who learning by song.
\end{abstract}

Keywords: Learning technique, personality type, listening skills

\begin{abstract}
Abstrak
Penelitian ini bertujuan untuk mengetahui pengaruh teknik pembelajaran dan tipe kepribadian terhadap keterampilan mendengarkan bahasa Inggris. Penelitian ini merupakan penelitian eksperimen dengan rancangan faktorial 2 × 2 yang dilaksanakan di SD Lab UNDIKSHA Singaraja. Siswa yang dilibatkan dalam penelitian sebanyal 88 orang, yang ditentukan secara acak melalui Multi stage random sampling technique. Hasil penelitian menunjukkan bahwa: (1) tidak terdapat perbedaan yang signifikan pada keterampilan mendengarkan bahasa Inggris antara siswa yang Bear dengan teknik pembelajaran permainan dan lagu, (2) keterampilan mendengarkan bahasa Inggris siswa yang berkepribadian ekstroversi lebih baik baik dari pada yang berkepribadian kontroversi, (3) terdapat pengaruh interaksi antara teknik pembelajaran dan tipe kepribadian terhadap keterampilan mendengarkan bahasa Inggris, (4) keterampilan mendengarkan bahasa Inggris siswa yang berkepribadian ekstroversi, yang belajar dengan teknik pembelajaran permainan lebih rendah dari pada yang belajar dengan teknik pembelajaran lagu, dan (5) keterampilan mendengarkan bahasa Inggris siswa yang berkepribadian kontroversi, yang belajar dengan teknik pembelajaran permainan lebih tinggi daripada yang belajar dengan teknik pembelajaran lagu.
\end{abstract}

Kata kunci: teknik pembelajaran, tipe kepribadian, keterampilan mendengarkan

\section{INTRODUCTION}

English has been pervasively studied in Indonesia since 1960s and it is officially regarded as the First foreign language to be studied in schools and universitas. This is obviously stated in the ministerial decree of
Education and Culture no. 096/1967 dated 12 December 1967. Furthermore, based on the government regulation no. 2 year 1989 concerning with the National Education System, it is mentioned that improvement of quality and Life status of Indonesian people 
is indicated by the ability to interact with other Nations efectively and efficiently through English (Hamid, 2003: 13). Regarding the policy of english instruction to Yong learners, the Department of National Education has recently recommended that English is allowed to be taught to students in elementary schools all over the country.

Considering the Fast that Bali is well known as One of the International tourist destinations in Indonesia, the local Authority Fund it necessary to introduce English in the primary level. Nowadays, almost all elementary schools in Bali, and in particular in Singaraja (North Bali) as the Place of concern in this study, have taught student English starting from Grande for to Grande Six. Even more, some schools have principally intriduced English since grade One.

In order to be able to actualize the new established curriculum, competencybased curriculum, the school should possess teachers who have adequate competence in conducting English instruction. However, the facts show that many elementary schools in Singaraja have not had teaching qualities as expected. Teachers, who are responsible for teaching English, are those who do not have backgorund Education in English. They are willing to take this responsibility only because they have a vested interest in English. The most recent mini research conducted in July 2010 proves that pamong 185 teachers in 132 elementary schools in Buleleng district and Sukasada district in Buleleng regency who handle the English intsruction in their schools, 105 teachers $(56,75 \%)$ have english Education background, while 80 of hem $(43,25 \%)$ do not possess it. Furthermore, pamong those having no english Education background, 46 teachers $(57,5 \%)$ are graduate of two year diploma of elementary school teacher Training (D2 PGSD), $26 \quad(32,5 \%)$ are graduates of undergraduate program (S1) who have various Educational background, such as Hindu religion studies $(26,92 \%)$ social Sciences comprising of Economic, geography, Management $(19,23 \%)$; family prosperity studies (PKK) and hoteliers $(7,69 \%)$; and the rests are las, Indonesian, and distance Education. The most important of all is that Six teachers $(13,64 \%)$ only have secondary Education background (five of them ari graduates of SPG and One is graduate of SMA), who are brave enough to teach English.

Besides, the government policy in giving English to students in the primary level has not yet been seriously followed up by employing qualified English teachers. This cam also be proved that for 185 teachers, 127 of hem $(68,65 \%)$ are honorary teachers, only $44(23,78 \%)$ are Permanent teachers (Civil Cervantes), and the rest, 13 ( $7.03 \%)$ are contracted teachers. The big number of honorary teachers signifies that the majority of teachers do not have Guarantee of employment, so that they may quit any time soon they find better jobs. These findings support Alwasilah (2004: 80) who pinpoints the fact that Indonesia has not yet prepared to face the opportunity and challange of providing professional English instruction.

The less professionalism is handling English instruction has impacts on teacher's ability to teach English. In teaching, some teachers expressed to the researcher that they generally gave more emphasis on the teaching of vocabulary with its pronunciation because they thought that vocabulary and pronunciation are important aspects of English. In terms of techniques of teaching, they said that they mainly adopted the conventional teaching technique, that is, translation from English to Indonesian or vice versa. In addition to teaching vocabulary, teachers also mentioned the importance of teaching grammar, the strategy 
taken to teach seemed to be more deductive, in which they generally gave rules and examples of sentences. Both vocabulary and grammar are improtant, but more importantly these two language components must be taught integratedly with language skills, such as, listening, reading, speaking, and writing. In the early stages of learning, especially for young learners, they are regarded as beginners in the foreign language learning, thus listening skill has to be given more emphasis rather than other skills.

According to Morley (2001: 70), listening skill is the first skill in language acquisition, which learners acquire long before they are able to produce the language (speaking). Therefore, comprehension of language items both vocabulary and grammar must be contextually introduced. Dealing with this, she states that listening comprehension, which focuses on teaching listening in every phases of learning is something very crucial in second language acquisition. While Denes and Pindon (1963: 1 as quoted by Morley, 2001: 70) argue that listening comprehension gives a foundation of oral language development in a speech chain of listening and speaking.

In order that the goal of learning is to be achieved, the use of appropriate techniques of teaching and learning should be optimized. The techniques must be suitable with the characteristics of young language learners who have not yet possessed sufficient knowledge of the language. Furthermore, young learners are characterized by their liking in play, so that a good learning is learning, which makes them study while playing in fun condition.

In relation to this study, the techniques promoted to be used in teaching listening skill are games and songs. On the one hand, Wright et al (2007:1) state that game is an activity which is entertaining and engaging, often challenging, and an activity in which the larners play and usually interact with others. They further convey that games are helpful and encourage learners to maintain their interest and learning activity. Games help teachers to create language context which makes the language useful and meaningful. Martin (in Brewster et al., 2007:172) affirms that game can provide young learners with fun activity which gives them the opportunity to practice the foreign language in a relaxed and enjoyable way. On the other hand, Brewster et al (2007: 162) convey that song is an ideal way to learn a language. Malley (in Murphey, 1992: 3-6) describes two main values of music and song, that is, songs are easy to memorize and highly motivating. Murphey further explains that songs are kept long in memory, and can be part of us. As well, they are easy to be used of in the classroom. It can thus be summarized that both games and songs are two techniques of teaching which give a lot of benefits with the essence of creating a fun learning atmosphere. Games and songs can facilitate improvement in young learners' listening skill.

Another important aspect which may affect language acquisition is personality. Elliot et al (2000: 30) mention that personality is one characteristic of biopsychosocial. Bio-psychosocial is the term used to understand individual variation consisting of three main elements, such as biological, psychological, and social which interact one another in every individual development. Biological element refers to genetic factor, psychological element focuses on all cognitive and personality aspects. While social element concers with influences from family, schools, teachers, and friends in the development. According to Kumaravadivelu (2006: 31-32) there are several individual factors which may affect L2 development. Among those factors are 
age, anxiety, empathy, extroversion, introversion, and risk tasking.

From those factors, the researcher focuses on the attitudes of extroversion and introversion in this study. The wat extrovert and introvert react can influence the process of language learning and the success they achieve. Therefore, teacher must be aware of this and be sensitive in selecting rechniques of teaching, which are suitable with students' types of personality, so that they are able to enhance learners' competence, particularly listening skill as the concern of this research.

\section{A. The Nature of Listening Skill}

Anderson and Krathwohl (2001: 274) generally define skill as follows:

Abilities and skills refer to organized modes of operation and generalized techniques for dealing with materials and problems.. the abilities and skill objectives emphasize the mental processes of organizing and reorganizing material to achieve a particular purpose.

More particularly, New Zealand Ministry of Education (2010: 1) defines language skill as an ability to use language knowledge and understanding to perform a language based or language-related task, such as filling in a form (writing skill) or getting the gist of a news broadcast (listening skill). Helgesen (2003: 24) describes listening as an active process which aims at creating meaning from what is heard. Meanwhile,Richards (2008: 3-15) views listening in two perspectives, namely: (1) listening as comprehension, and (2) listening as acquisition. Listening as comprehension is a traditional way o thinking the nature of listening. In this way, listening and listening comprehension are two synonymous terms. This view is based on the assumption that the main function of listening in second language is to facilitate comprehension of oral discourse. While listening in acquisition views listening as a part of language development. Language development occurs if learners develop ability in features of language input, then internalize those new language items in their language repertoire by making used of the language items in producing oral language.

\section{B. The Role of Listening Skill to Elementary School Students}

Many experts in education view that listening skill is necessary to be given emphasise from early stage of learning because good listening competence will give a positive impact to the second language development. In relation to this, Rost (as quoted by Nunan, 2004: 238-239)points out that listening is a very vital skill in language class because through listening learners receive various inputs.

From all the aforementioned views, a conclusion can be drawn that listening skill has a very important role in the second language development. Through listening learners not only learn various language aspects, such as sound system, words, sentences (sytax), and pronunciation, but also gain a foundation to develop further language skills, like speaking or oral communication. Therefore, students must be given as optimum exercies as possible.

\section{Kind of Listening Skill}

Harmer (2007: 134) explains two kinds of listening and extensive listening. Intensive listening occurs when learners listen specifically to train their listening skill, and the way how English is uttered. Intensive listening generally occurs in the classroom or in language laboratory, and it is made to happen with the presence of the teacher in guiding learners in the learning process. Meanwhile, extensive listening refers to listening which is usually done by learners 
outside the classroom. It normally aims for enjorment or other reasons.

The benefit of intensive listening using audio material is that through recorded material, learners are able to listen to various voices besides their teacher. They have opportunities to learn several characters taking part in the conversation. In addition to intensive listening through recorded materials, learners are also able to train their listening skill by live listening. Field (2000: 34 as quoted by Harmer, 2007: 304-306) points out that live listening is useful for learners to train their listening ability through face to face interaction, to train strategies to repair communication. Hence, the kind of listening under consideration in this research is intersive listening since learners do activities in language learning in the classroom under a teacher's guidance.

\section{Technique of Teaching Using Games}

Wright et al. (2008: 2) and Ersoz (2008:1) admit that teaching language is a hard work and sometimes frustating. Therefore, various activities any time need to be conducted. According to Wright et al., one activity can be carried out to avoid this is using games.

Elliot et al. (2000: 75) explain that a game is an activity which is done by children because they enjoy it. Similarly, Wright et al. (2007: 1) state that game is an activity which is entertaining and engaging, often challenging, and an activity in which the learners play and usually interact with others.

The above statement indicates that games are excellent teaching techniques to teach the integration of various language aspects which are able to increase learners' motivation to learn. Another benefit of games is that learners are able to acquire the language indirectly since their attention is focused on the message rather that the language itself.

\section{E. Technique of Teaching Using Songs}

Song is defined as short voice, usually simple, either accompanied or not by musical instrument (Britannica Concise Encyclopedia, 2010: 1). Flattum (2004:1) further notes that a song is a combination of melody and lyrics, which are enlightend by addition of harmony and rhythm or beat. It has structure, usually repeats of verses and choruses. Hence, it can be said that a song is a combination of melody and lyrics or a composition of words and music, which has structures in the dorm of repeats of verses and choruses, is either accompanied or not by musical instrument.

In accordance to Murphey, Paul (2003: 58) states as below:

Songs add a whole dimension to children's classes, and make it easier for the children to remember words and patterns and natural chunks of language. Songs can add feeling and rhythm to language practice that might otherwise be flat, help children remember things more easily, and draw children more deeply into a lesson. Thus, it can be concluded that there are several forms of songs, namely nursery rhymes, comtemporary songs, and special songs written for English Language teaching. They can be taught in many different ways. Among others are ostensive way, translation, cloze text, true-false statement, jigsaw, focusquestion, disappearing text and even mixed presentation.

\section{F. Types of Personality}

Extroversion and introversion are two individual factors which are parts of the personality. Schultz states:

Much of our conscious perception of and reaction to the world around us is determined by the attitudes of extroversion and introversion. These two attitudes are probably the best-known parts of Jung's 
system, the terms and concepts have come into general prominence (Schultz, 1982:61). Furthermore, Jung (1961. As quoted by Ryckman, 2008: 89) states: Extroversion refers to an outgoing candid, and accomodating nature that adapts easily to a given situation, quickly forms attachments, and setting aside any possible misgivings, often ventures forth with careless confidence into an unknown situation. Introversion, in contrast, signifies a hesitant, reflective, retiring nature that keeps itself to itself, shrinks from obsjects, is always slighly on the defensive, and prefers to hide behind the mistrustful scrutiny.

Therefore, from all the above theories, it can be sythesized that extrovert and introvert personalities could be seen from four major characteristics which are in contradictory. Extrovert personality is more communicable, open, frank, adventurous, and sociable, on the other hand, introvert personality is more silent (solitary), secretive, cautious, and reclusive.

\section{RESEARCH METHODOLOGY}

This research was mainly intended to obtain empirical findings on the effect of teaching techniques and types of personality towards the students English listening skill. Operationally, it was aimed at finding the data in three ways: (1) the use of teaching techniques, (2) types of peronality, and (3) English listening skill of elementary students.

This research was carried out in SD Lab UNDIKSHA Singaraja in the first semester in the academic year 2009/2010 for six months starting from July until December 2009 with the total number of 12 effective teaching sessions.

This research used an experimental method, in which treatments were assigned to two different groups as the samples of research. The two groups were then randomly determined as either an experimental group or a control group. The experimental group was treated with the game technique, while the control group was treated with the song technique. Regarding that there was more than one independent variable to be tested, thus this research used a $2 \times 2$ factorial design.

The population of this research was all students at SD Lab UNDIKSHA Singaraja in the first semesnter in the academic year $2009 / 2010$ with the total number of 438 students ranging from the first grade to sixth grade. As the coverage of the population was large, multi stage random sampling technique was used to select an appropriate number of samples. First. Purposive sampling was carried out to determine the school taken for investigation, in this case SD Lab UNDIKSHA Singaraja. The next step was cluster sampling to determine samples as one intact group. Since the school had six grades, then random sampling technique was udes to determine the sample among the six grades. Due to the randomization, the grade taken was grade four. The next sampling technique was again random sampling in order to determine either class A or class B to be the experimental group or the control group. The result of the randomization determine class $\mathrm{B}$ as the experimental group (being taught using the game technique), while class $\mathrm{A}$ as the control group (being taught using the song technique).

There were 88 students in these two classes, in which each consisted of 44 students. Thus, the experimental group had 44 students, while the control group also had the same number. The scores gained by the students in their personality questionnaires were then used to determine either $30 \%$ high to be the extrovert group or $30 \%$ low to be the introvert group. The total number of students in either extrovert group or introvert group was 13 students respectively. The instruments employed to collect the data 
were of two types: (1) listening test which was meant to measure the effect of the teaching techniques on the students' listening skill, and (2) questionnaire which was used to determine the types of students' personality. Before being executed, the instruments were tried out. It was tried out twice. In the first try out, it was conducted in SD Mutiara Singaraja, which involved 43 fourth graders. Finfing that the valid items were not representative for each aspect of both listening skill and personality, the second try out was held in SD No. 3 Banjar Jawa Singaraja. The try out in the later school was participated by 37 fourth graders. For the listening test, the validity was analyzed using Coefficient Correlation Point Biserial and its reliability was measured using KR-20. Meanwhile, for the personality questionaire, the validity was analyzed using Coefficient Correlation Product Moment and its reliability was measured using Alpha Cronbach.

The collected data were then analyzed in two ways, descriptive statistics and inferential statistics. In descriptive statistics, the data were descibed to determine Mode, Median, Range, Mean Score, and Standard Deviation. The mean score from each group was described and compared. The inferential statistics analysis was carried out using twoway analysis of variance (ANOVA) at the level of significance $\alpha=0,05$ to determine the effect of independent variable on the dependent variable. The interaction effect was also examined in this study.

When the findings showed that the mean scores of extrovert and introvert students on their listening skill significantly diferred regarding the execution of the different teaching techniques, multiple comparison procedure (Post Hoc Multiple Comparison) was applied to determine which pairs or combinations of mead scores differed. Based on the fact that the samples of each cell were the same, 13 students, then the technique of multiple comparisons applied was Tuckey test. It was employed to find out which technique maximally affected the listening skill from the two groups, extroversion or introversion. Before handling statistical analysis, normality test and homogenity test were performed. Liliefors test was applied to test the normality of score distribution, while Bartlet test was utilized to determine the homogenetity of variance on the level of significance of $\alpha=0,05$.

\section{RESEARCH FINDINGS AND DISCUSSION}

The research findings comprise data description, normality and homogeneity testings, inferential statistics analysis, hypothesis testing and discussion, and limitation of research.

\section{A. Data Description}

Data description covers the explanation of the scores gained by the students in their listening skill test. There are eight classification of data, namely (1) the listening skill scores of the students being taught using the game technique, (2) the listening skill scores of the students being taught using the game technique, (3) the listening skill scores of the extrovert students, (4) the listening skill scores of the introvert students, (5) the listening skill scores of the extrovert students being taught using the game technique, (6) the listening skill scores of the introvert students being taught using the game technique, (7) the listening skill scores of the extrovert students being taught using the song technique, and (8) the listening skill scores of the introvert students being taught using the song technique. The first two classifications of data description can be seen in table below: 
Tabel 1. Data Description of Listening Skill Scores of Students Being Taught Using The Game Technique (A1) and The Song Technique (A2)

\begin{tabular}{|l|c|c|}
\hline & Game (A1) & Song (A2) \\
\hline $\mathrm{N}$ & 44 & 44 \\
\hline Mean & 44.23 & 44.73 \\
\hline Median & 44.00 & 44.50 \\
\hline Mode & 43.00 & 55.00 \\
\hline Standard Deviation & 6.18 & 9.07 \\
\hline Variance & 38.13 & 8.24 \\
\hline Range & 25.00 & 30.00 \\
\hline Minimum & 32.00 & 30.00 \\
\hline Maximum & 57.00 & 60.00 \\
\hline Sum & 1946.00 & 1968.00 \\
\hline
\end{tabular}

For the next data description, that is, for the classification number 3 and number 4 , the data are presented in the following table

Tabel 2. Data Description of Listening Skill Scores of Students Having Extrovert Personality (B1) and Introvert Personality (B2)

\begin{tabular}{|l|c|c|}
\hline & Extrovert (B1) & Introvert (B2) \\
\hline $\mathrm{N}$ & 26 & 26 \\
\hline Mean & 52.8 & 39.42 \\
\hline Median & 53.50 & 38.50 \\
\hline Mode & 55.00 & 36.00 \\
\hline Standard Deviation & 5.66 & 6.22 \\
\hline Variance & 32.01 & 38.73 \\
\hline Range & 20.00 & 24.00 \\
\hline Minimum & 40.00 & 30.00 \\
\hline Maximum & 60.00 & 54.00 \\
\hline Sum & 1362.00 & 1025.00 \\
\hline
\end{tabular}

The data description dealing with the rest classfications, number 5,6,7, and 8 , are shown in the following table:

\begin{tabular}{|l|c|c|c|c|}
\hline & A1B1 & A1B2 & A2B1 & A2B2 \\
\hline $\mathrm{N}$ & 13 & 13 & 13 & 13 \\
\hline Mean & 48.69 & 42.23 & 56.08 & 36.62 \\
\hline Median & 50.00 & 43.00 & 55.00 & 36.00 \\
\hline Mode & 44.00 & 43.00 & 55.00 & 36.00 \\
\hline $\begin{array}{l}\text { Standard } \\
\text { Deviation }\end{array}$ & 5.20 & 5.26 & 3.17 & 5.99 \\
\hline Variance & 27.06 & 27.69 & 10.08 & 35.92 \\
\hline Range & 17.00 & 19.00 & 10.00 & 21.00 \\
\hline Minimum & 40.00 & 35.00 & 50.00 & 30.00 \\
\hline
\end{tabular}


Jurnal Parameter Volume 29 No. 1

DOI : doi.org/10.21009/parameter.291.07

P-ISSN : 0216-261X

\begin{tabular}{|l|c|c|c|c|}
\hline Maximum & 57.00 & 54.00 & 60.00 & 51.00 \\
\hline Sum & 633.00 & 549.00 & 729.00 & 476.00 \\
\hline
\end{tabular}

\section{Normality Test}

The normality test was carried out to the four groups of data, the scores of listening skill of extrovert group being taught using the game technique (A1B1), the scores of listening skill of introvert group being taught using the game technique (A1B2), the scores of listening skill of extrovert group being taught using the song technique (A2B1), and the scores of listening skill of introvert group being taught using the song technique (A2B2).

In testing the normality of the scores, the level of significance being applied was $\alpha=$ 0,05 and $\mathrm{n}=13$, with the value of $\mathrm{Lt}=0,234$. The summary of the normality test result is presemted in the following table

Tabel 3. Summary of Normality Test

\begin{tabular}{|c|c|c|c|c|}
\hline Group & Listening Skill & Value of Lo & Value of Lt & Conclusion \\
\hline 1 & A1B1 & 0.1457 & 0.234 & Normal \\
\hline 2 & A1B2 & 0.2096 & 0.234 & Normal \\
\hline 3 & A2B1 & 0.1716 & 0.234 & Normal \\
\hline 4 & A2B2 & 0.1923 & 0.234 & Normal \\
\hline
\end{tabular}

The above table shows that all groups of data, which were analyzed using Liliefors Test, gained Lo lower than Lt on the level of significance $\alpha=0,05$. This means that all groups of data in this research were from samples which had a normal distribution. Hence, the normality requirement was accomplished. Thus, further analysis could be conducted.

Homogeneity Test

\begin{tabular}{|c|c|c|c|}
\hline Group of Data & $X_{O}^{2}$ & $X_{1}^{2}$ & Conclusion \\
\hline $\mathrm{An}_{1} \mathrm{~B}_{1}$ & \multirow{2}{*}{4.73671446} & 7.815 & Homogeneous \\
\cline { 1 - 1 } $\mathrm{A}_{1} \mathrm{~B}_{2}$ & & & \\
\cline { 1 - 1 } $\mathrm{A}_{2} \mathrm{~B}_{1}$ & & & \\
\hline $\mathrm{A}_{2} \mathrm{~B}_{2}$ & & & \\
\hline
\end{tabular}

From the above table, it can be seen that all groups of data which were analyzed for their homogeneity using Bartlett Test obtained the value of $\mathrm{Lo}=4.74$, which was less than the value of $\mathrm{Lt}=7.815$. this means that the group of data came from samples which had homogeneous variance. Thus, the requirement of homogeneity was achieved.
Another test required to do is homogeneity test of variance for the four groups of data. These groups should also fulfill the assumption that the variance is homogeneous. So that further analysis could be carried out. The result of the analysis using Bartlett Test on the level of significance= 0,05 and the degree of freedom $=3$ is presented in the table below. 
In order to be able to test the hyphoteses, a two-way analysis of variance ( 2 x 2 ANOVA) was carried out. This was intended to investigate the different effect of treatment of the techniques of teaching (game

\begin{tabular}{|c|c|c|c|c|c|c|}
\hline $\begin{array}{c}\text { Source of } \\
\text { Variance }\end{array}$ & df & SS & MS & Fo & \multicolumn{2}{|c|}{ Ft } \\
\cline { 1 - 3 } $\begin{array}{c}\text { Teaching } \\
\text { Technique (A) }\end{array}$ & 1 & 10.173 & 10.173 & 0.404 & 4.04 & 7.19 \\
\hline Personality (B) & 1 & 2184.019 & 2184.019 & 86.705 & & \\
\cline { 1 - 4 } $\begin{array}{c}\text { Interaction A x } \\
\text { B }\end{array}$ & 1 & 549.250. & 549.250 & 21.805 & & \\
\hline Between Group & 3 & 2743.442 & 914.481 & 36.305 & 2.80 & 4.22 \\
\hline Within Group & 48 & 1209.077 & 25.189 & & & \\
\hline Sum & 51 & 3952.519 & & & & \\
\hline
\end{tabular}

Note:

df: degree of freedom

SS: Sum of Square

MS: Mean of Square

On the basis of the results of a two-way analysis of variance (ANOVA), it can be drawn some conclusions of the findings as follows:

a. The result of calculation which shows that $\mathrm{Fo}(\mathrm{A})=0.04<\mathrm{Ft}=4.04$ on the level of significance $\alpha=0.05$. this means that Ho is accepted, while $\mathrm{Ha}$ is rejected. Thus, there is no significant difference on English listening skill between the students who learn using the game technique and the song technique.

b. The result of calculation which shows that $\mathrm{Fo}(\mathrm{B})=86.705>\mathrm{Ft}=4.04$ on the level of significance $=0.05$ and $\mathrm{Ft}=7.19$ on the level of significance $=0.01$. this means that Ho is rejected, while $\mathrm{Ha}$ is accepted. Therefore, there is a very significant difference on English listening skill between the students having extrovert personality and those having introvert personality.

c. The result of calculation which shows that $\mathrm{Fo}(\mathrm{AB})=21.805>\mathrm{Ft}=4.04$ on the level of significance $=0.05$ and $\mathrm{Ft}=7.19$

on the level of significance $=0.01$. This means that Ho is rejected, while $\mathrm{Ha}$ is accepted. Hence, there is a very significant interaction between the techniques of teaching and types of personality on English listening skill.

Regardless of the findings which have been presented above, the researcher found some limitations of the research which should be taken into consideration for further research. Those limitations are as follows:

First, this research merely involved the elementary students of SD Lab UNDIKSHA Singaraja at semester 1 in the academic year 2009/2010. So that the conclusion drawn only concerns with the students in this school.

Second, the design employed for this research was an experimental research, in which all variables had to be controlled tightly. However, it is realized that there were still undetected variables which could have an effect on the result. As an example, the treatment was held once a week and in every session there were also other lessons besides 
English that should be studied by the students. As well, there was only a little portion of time dedicated for handling the treatment. This indicated that there was a tendency that other variables could influence the listening skill in the English teaching learning process.

Third, there was no pre-test conducted before treatment with an assumption that the students' previous listening skill was homogeneous. Fourth, the classification of personality which divided the students into two, extrovert and introvert using $30 \%$ above and $30 \%$ below from the questionnaire scores, put aside the students in the middle $(40 \%)$, so that the confusion drawn had to be taken carefully.

Fifth, the first hypothesis which proves that there is no significant difference on the English listening skill between the students who learn using the game technique might be influenced by the fact that all of the fourth grade students under investigation were by any chance completed their kindergarten level before entering their primary education, so that they were accustomed to being taught using both games and songs.

The last limitation is related to the preparation of gamed and songs. It takes much time to prepare the games and songs which suit the themes of teaching material. More importantly, looking for the ready gamed and song in the market which are appropriate with the teaching material will be a difficult and challenging task for the teacher.

\section{CONCLUSION}

Regarding the results of findings previously clarified, there are five hyphotehes which have been analyzed, namely: (1) there is no significant difference on English listening sill between the students who learb using the game technique and those who learn using the song technique.
This proves that games are as good as songs being applied to teach listening skill to elementary school students.

This finding is understandable an enjoyable atmoshphere of learning process. So that both groups treated differently can achieve good listening skill which do no different significantly; 2) there is a very significant difference on English listening skill between the students having extrovert personality and introvert personality. This proves that types of personality have an impact on the success of second language learning. In this research, the students having extrovert personality gain better listening skill than those of the introvert personality; 3) there is a very significant interaction effect between teaching techniques and types of personality on listening skill. On one hand, the extrovert students gain a better listening skill being taught using the song technique rather than the game technique, on the other hand, the introvert students obtain better listening skill being taught using the game tecnique rather than song technique, 4) there is a significant difference on listening skill between the students having extrovert personality who learn using the game technique and those of the same group who learn using the song technique. The extrovert students who learn using the game technique and those of the same group who learn using the game technique achieve lower listening skill than those wxtrovert ones who learn using the song technique than the game technique; and (5) there is a significant difference between the students having introvert personality who learn using the game technique and those of the same group who learn using the song technique. The introvert students who learn using games achieve higher listening skill than those of the same group who learn using the songs. Therefore, it can be stated that the introvert 
students are more suitable being taught using the game technique than the song technique.

\section{REFERENCES}

Abdul, H. F. (2003). "Kebijakan Pengajaran Bahasa Inggris Sebagai Bahasa Asing di Indonesia". Revitalisasi Pendidikan bahasa, ed. A. Chaedar Alwasilah dan Hobir Abdullah. Bandung: CV. Andira.

Alwasilah, A. C. (2004). Perspektif Pendidikan Bahasa Inggris di Indonesia. Bandung: CV. Andira

Alwisol. (2005). Psikologi Kepribadian. Malang: UMM Press.

Anderson, L. W., \& Kratwohl, D. R. (2001). A Taxonomy for Learning Teaching, and Assessing: A Revision of Bloom's Taxonomy of Educational Objectives. New York: Addison Wesley Longman.

Bailey, R., Doherty, J., \& Jago, R. (2004). “ Physical Development and Physical Education". Learning in the Early Years: A Guide for Teachers of Children 3-7, ed. Jeny Riley. London: Paul Chapman Publishing, A SAGE Publications Company.

Brewsten, J., Ellis, G., \& Girard, D. (2007). The Primaru English Teacher's Guide. Essex. England: Pearson Education Limited.

Cameron, L. (2008). Teaching Languages to Young Learners. Cambridge: Cambridge University Press

Djaali, \& Muljono, P. (2004). Pengukuran dalam Bidang Pendidikan. Jakarta: PPs Universitas Negeri Jakarta.
Dockett, S., \& Fleer, M. (2002). Play and Pedagogy in Early Childhood: Bending the Rules. Victoria: Nelson Australia Pty Limited.

Feez, S. (2010). Montessori and Early Childhood. London: SAGE Publications Ltd.

Gay, L. R., Geoffrey, E., Mills., \& Peter Airasian. (2009). Educational Research: Competencies for Analysis and Cpplication. Pearson Education, Inc.

Harmer, J. (2007). The Practice of English Language Teaching. Essex: Pearson Education Limited.

Hetherington, E., \& Mavis et al. (2006). Child Psychology: A Contemporary Viewpoint. New York: McGraw-Hill, a Business unit of The McGraw-Hill Companies, Inc.

Iskandar, Y. (2005). Tes Personaliti. Jakarta Selatan: Yayasan Dharma Graha.

Klein, K. (2005). Teaching Young Learners. English Teaching Forum, 43 (1): 1217.

Kumaravadivelu, B. (2006). Understanding Language Teaching: From Method to Postmethod. New Jersey: Lawrence Erlbaum Associates, Inc.

Lo, R., \& Henry, C. F. L. (1998). Songs Enhance Learner Involvement. Forum, 36 (3): 8-11

McCrae, R. R., \& Costa, P. T, Jr. (2006). Personality in Adulthood: A FiveFactor Theory Perspective. New York: The Guilford Press. 
McKay, P. (2007). Assessing Young Language Learners. Cambridge: Cambridge University Press.

Moon, J. (2000). Children Learning English. Oxford: Macmillan Publishers Limited

Nunan, D. (2004). Listening in Language Learning, Methodology in Language Teaching: An Anthology of Current Practice, ed. Jack C. Richards and Willy A. Renandya.

Paul, D. (2003). Teaching English to Children in Asia. Hong Kong: Pearson Education Asia Ltd.

Ralibi, I. M. (2008). Fun Teaching: Kiat Sukses Belajar dan mengajar yang Menyenangkan. Cikarang: Duha Khazanah Duha Publishing.

Ross, J. (2007). Designing Lessons for EFL Listening Comprehension Classes. English Teaching Forum, 45 (3): 30-33

Ryckman, R. M. (2008). Theories of Personality. Belmont, CA: Thomson Wadsworth

Sudjana. (2005). Metoda Statistika. Bandung: Tarsito.

Sugiyono. (2007). Metode Penelitian Kuantitatif, Kualitatif, dan R\&D. Bandung: Alfabeta

Tirtahardja, U. (2005). Pengantar Pendidikan. Jakarta. PT. Rineka Cipta

Wilson, J. J. (2008). How to Teach Listening. Essex: Pearson Education Limited. 